\title{
DROUGHT RISK ASSESSMENT IN THE KOPEL RIVER BASIN
}

\author{
Mariusz Sojka', Joanna Jaskuła', Izabela Wielgosz' \\ 1 Institute of Land Improvement, Environmental Development and Geodesy, Faculty of Environmental \\ Engineering and Spatial Management, Poznan University of Life Sciences, Piątkowska 94 Str., 60-649 Poznań, \\ Poland, e-mail: masojka@up.poznan.pl, jaskula@up.poznan.pl
}

Received: 2017.07.15

Accepted: 2017.08.28

Published: 2017.11.01

\begin{abstract}
The main aim of the study was to assess drought risk in the Kopel river basin on the basis of analysis of observations made in the period from 1972 to 2011 . The Kopel river is a right tributary of the Warta river which it joins at $254+600 \mathrm{~km}$. The drought risk was assessed on the basis of meteorological and hydrological diurnal data. The trend analysis revealed that temperature has a significant increasing tendency. On the basis of SNQ and Q70\% flows the indices such as drought duration and drought volume were computed. Statistical analysis showed negative correlations between drought indices and precipitation. The results presented in this study indicated that drought risk in the Kopel river basin is high.
\end{abstract}

Keywords: lowland river, drought indices, drought assessment

\section{INTRODUCTION}

In recent years, climate change has become one of the biggest issues on the global, regional and local scale [European Environmental Agency 2008, Francés et al. 2017, Huang et al. 2015b]. Climate changes have a substantial impact on water resources. In recent decades an increase in the frequency and severity of droughts has been observed in Poland. Droughts can be divided into three types: meteorological, soil and hydrological [Esfahanian et al. 2017, Haro-Monteagudo et al. 2017, Huang et al. 2016, Huang et al. 2017]. Meteorological drought is defined as a period of precipitation scarcity when compared to the longperiod average [Bąk et al. 2012, Esfahanian et al. 2017]. Soil drought is associated with soil moisture deficits that cause reduction in vegetation development and crop yields [Li et al. 2016]. Hydrological drought is related to changes in the ground and surface water level and discharge disturbance.

Droughts are defined as a extreme natural disasters [Huang and Chou 2008, Mishra and Singh 2010, Pathak et al. 2016] that cause significant agricultural, social and economic damage [David and Davidová 2016, Huang et al. 2015a,
Li et al. 2016., Masud et al. 2015, Zhang et al. 2015]. Additionally, their occurrences, spatial extend and severity is difficult to predict [Baryła et al. 2016, Hatmoko et al. 2015]. The consequences of drought are not immediate, its effects are felt over greater area and are more extended in time than those of other natural phenomenon [Łabędzki 2004].

A decrease in the water resources has been observed in many European countries over recent years [Kędziora et al. 2014]. Water resources in Poland are characterized by high temporal and spatial variability. In over $75 \%$ of country area water scarcity is a regular occurrence. The most vulnerable are the regions located in the central part of Poland: Kujawsko-Pomorskie, Mazowieckie and Wielkopolskie. Especially the Wielkopolska and Kujawy regions are characterized by small amount of annual precipitation from 450 to $500 \mathrm{~mm}$.

In order to protect the most sensitive areas in Poland, the Ministry of the Environment and the Institute for the Environmental Protection, a National Research Institute, have started the project on Managing the Risks of Extreme Events and Disasters to Advance Climate Change Adaptation 
to 2020'(SPA 2013). The main aim of the SPA introduction [2013] was to undertake all kinds of measures that would ensure sustainable development and effective functioning of the economy and society sectors in climate change conditions up to 2020. In order to describe the results of monitoring and to help assess the extend and effects of drought, the special drought-related indices have been introduced [Wang et al. 2015]. A majority of drought indices were described and used in Poland [Kanecka-Geszke and Smarzyńska 2007, Kręgiel and Jarosińska 2009, Łabędzki and Bąk 2004, Tokarczyk 2008].

The aim of this study was to assess the future drought risk in the Kopel river basin on the basis of the observations made over the period 1972-2011. The utilitarian aim was to propose activities and operations that should be carried out in the river basin to limit the drought effects.

\section{MATERIALS AND METHODS}

The drought risk in the Kopel River basin was evaluated on the basis of the data provided by the Institute of Meteorology and Water Management, a National Research Institute (IMGW-PIB) in Warsaw. The meteorological conditions in the years 1971-2015 in the Kopel river basin were characterized on the basis of daily measurements of precipitation and air temperature at the Kórnik meteorology station. The hydrological conditions in the river basin area were characterized on the basis of daily measurements of discharge at the Głuszyna gauge station.

The boundaries of the basin were designated on the basis of the Raster Hydrographical Map of Poland (MPHP) in the scale 1:50 000 [2010], provided by the National Agency for Water Management (KZGW). The abiotic type of the surface water bodies was determined on the basis of the Report of the Ministry of Environment for the river Odra basin [2005]. Basic terrain analysis was made on the basis of the Digital Terrain Model (DTM) of the mesh size 100 m, provided by the Geodetic and Cartographic Documentation Centre (CODGiK). The structure of land cover was characterized on the basis of the digital database Corine Land Cover (CLC) obtained from the Chief Inspectorate for Environmental Protection (GIOŚ).

The drought risk assessment was evaluated on the basis of two parameters: SNQ (mean of minimum flows over the years 1971-2011) and Q70\% (Q70\% was determined from flow duration curves - FDCs). In the first step the value of SNQ and Q70\% were calculated. In the second step the drought indices (duration and volume) were computed for each year respectively. In the third step the annual mean, median, minimum and maximum values of the indices and standard deviations were calculated. Next the analysis, the correlation analysis was conducted. It was performed to find the relations between the meteorological parameters and drought indices. Finally, trends analyses were performed on the basis of testing the hypotheses of zero slope of the regression curves. To present the drought risk, the daily flows of dry years (selected on the basis of annual minimum flow values) were presented on the background of flow duration curve in the period 1972-2011. Statistical analyses were carried out at the level of significance $\mathrm{p}_{\alpha}=0.05$ in the STATISTICA 13 software [StatSoft, Inc. 2017].

\section{RESULTS}

The Kopel river is a right tributary to the Warta river which it joins at $254+600 \mathrm{~km}$. The total area of the river basin is $423.72 \mathrm{~km}^{2}$, while the length of the river is $32.38 \mathrm{~km}$. In the Polish classification system of hydrographic basins this basin has been labelled with the code number 18574. According to abiotic typology, three surface water bodies in the basin were identified: Kopel from source to Głuszynka river inflow (PLRW600016185747) is lowland loess or clay stream, Kopel from Głuszynka river inflow to the mouth (PLRW600020185749) was classified as lowland gravel river and Głuszynka river (PLRW6000251857489) is stream connecting lakes. The code of the Kopel river basin groundwater bodies is 62 (PLGW600060).

According to the physico-geographic division proposed by Kondracki [2002], the basin is located in the Równina Wrzesińska (97.65\% of total basin area) and Kotlina Śremska (2.35\% of total basin area). The Kopel river basin has lowland character, the altitudes of the terrain vary from 54.3 to $135.0 \mathrm{~m}$ a.s.1. (Fig. 1). The mean altitude of the basin area is $94.65 \mathrm{~m}$ a.s.l. The mean slope of the basin is $5.50 \%$. The total length of rivers is $481.19 \mathrm{~km}$, which - with respect to the total basin area - gives density of river network equal to $1.14 \mathrm{~km} \cdot \mathrm{km}^{-2}$. All physiographic parameters are presented in Table 1. 


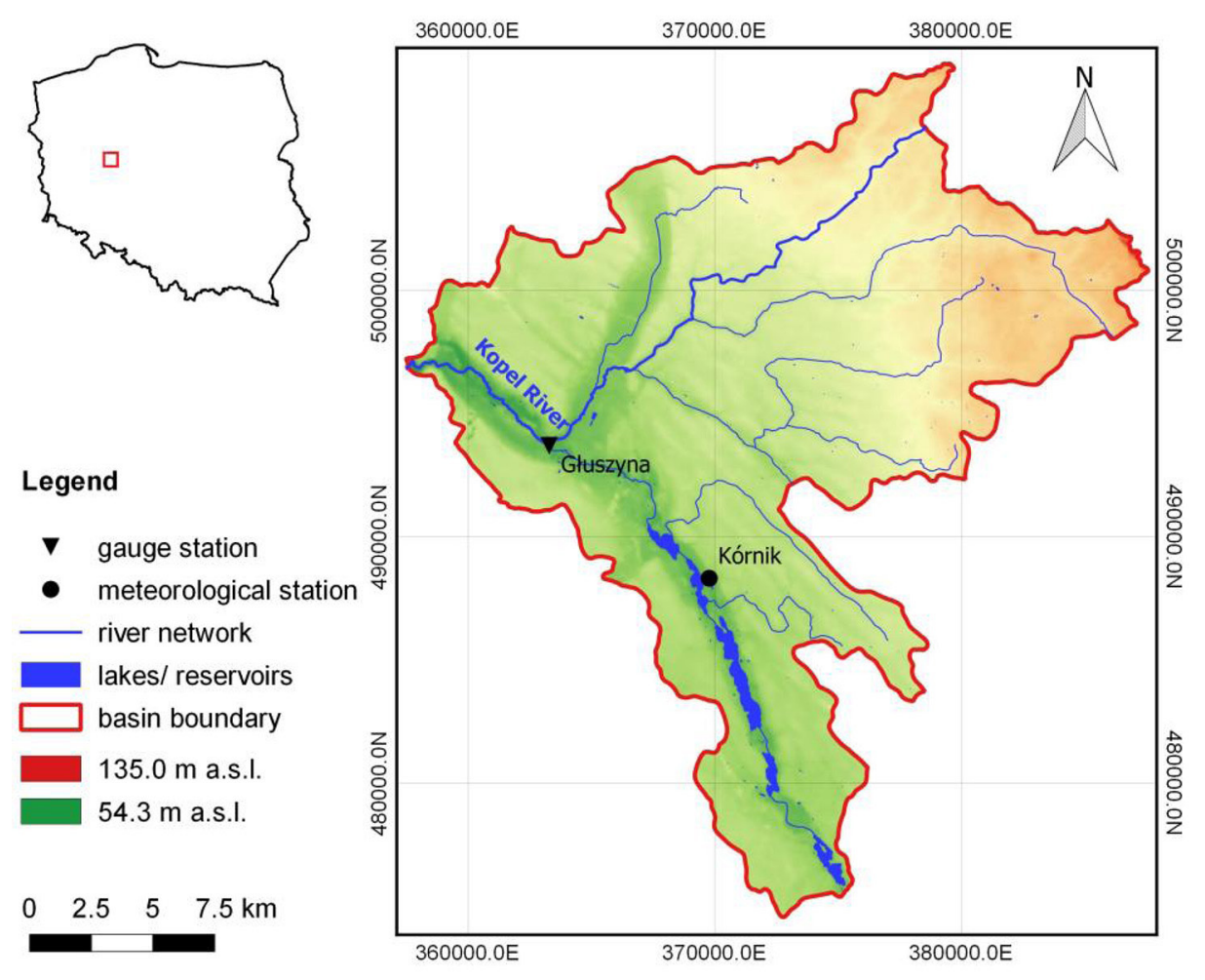

Fig 1. Study site location

According to the Corine Land Cover database, the basin area is mainly covered by agricultural land, occupying $77.87 \%$ of the basin area. The other forms of land cover are forests (13.69\%) and artificial surfaces (7.47\%). The total area of surface water bodies is $4.11 \mathrm{~km}^{2}$ which gives the lake index of $0.97 \%$.

Taking into regard the administrative division, the Kopel river basin is located in the central part of Wielkopolska region and occupies 10 communes - Dominowo, Kleszczewo, Kostrzyn, Kórnik, Mosina, Poznań, Swarzędz, Śrem, Środa Wielkopolska and Zaniemyśl.

The Kopel river basin is located in the Central Greater Poland and Central Poland Climatic Region (Woś, 1993). Over the years 1972-2011 the annual mean temperature was equal to $8.7^{\circ} \mathrm{C}$. The warmest was the year 2007 with the annual mean temperature of $10.5^{\circ} \mathrm{C}$, while the coldest was the year 1996 with the annual mean of $6.6^{\circ} \mathrm{C}$ (Fig. 2A). The annual mean sum of precipitations was equal to $568 \mathrm{~mm}$. The mean annual precipitations varied in a wide range. The lowest annual precipitation of $501 \mathrm{~mm}$ was observed in 1990, while the highest of $742 \mathrm{~mm}$ in 1994 (Fig. 2B).

The annual mean flow of the Kopel river in the Głuszyna gauge station in the period 1972-2011, was $1.19 \mathrm{~m}^{3} \cdot \mathrm{s}^{-1}$, with the minimum of $0.021 \mathrm{~m}^{3} \cdot \mathrm{s}^{-1}$ in 1983 and the maximum of $15.0 \mathrm{~m}^{3} \cdot \mathrm{s}^{-1}$ in 2011 . The mean of minimum flows (SNQ) was equal to $0.134 \mathrm{~m}^{3} \cdot \mathrm{s}^{-1}$. The value of Q70\% was $0.36 \mathrm{~m}^{3} \cdot \mathrm{s}^{-}$ ${ }^{1}$. The outflow index from the basin area was 89 $\mathrm{mm}$, while the unit outflow was $2.82 \mathrm{dm}^{3} \cdot \mathrm{s}^{-1} \cdot \mathrm{km}^{-2}$

On the basis of SNQ values analysis, it has been shown that in the period 1972-2011 the mean yearly drought duration was 48 days, with the range of 5 to 139 days (Table 2). Over the analyzed years, the total duration of drought was 1063 days. In these conditions, the mean annual drought volume was $0.183 \cdot 10^{6} \mathrm{~m}^{3}$, while the total volume over the period was $4.02 \cdot 10^{6}$ $\mathrm{m}^{3}$. The number of years with no drought period was 18 (Fig 2C).

The annual mean drought duration in the Kopel river basin in the years 1972-2011 based on Q70\% was 115 days, with the minimum of 19 days and the maximum of 303 days (Table 2). The total duration of drought was 4503 days. In these conditions, the annual drought volume varied from 0.13 in 1980 to $4.9310^{6} \mathrm{~m}^{3}$ in 1983 (Fig 2D). Over the years 1972-2011 the total volume of drought was $60.60 \cdot 10^{6} \mathrm{~m}^{3}$. The number of years with no drought period was equal to 1 (Fig 2C).

Figure 3 shows in the background the multiyear flow duration curve in the Kopel river in the period 1972-2011, while in the foreground 
Table 1. Main physiographic parameters of the Kopel river basin

\begin{tabular}{|c|c|c|c|}
\hline Parameter & Formulae & Symbol, Unit & Value \\
\hline Total area & - & $\mathrm{A}\left[\mathrm{km}^{2}\right]$ & 423.72 \\
\hline Basin perimeter & - & $\mathrm{P}[\mathrm{km}]$ & 146.42 \\
\hline Maximum basin length & - & $L_{m}[k m]$ & 33.38 \\
\hline Mean width of the basin & $\frac{A}{L_{m}}$ & $\mathrm{~B}[\mathrm{~km}]$ & 12.69 \\
\hline Basin elongation ratio & $\frac{2}{L_{m}} \sqrt{\frac{A}{\pi}}$ & $\mathrm{C}_{\mathrm{w}}[-]$ & 0.70 \\
\hline Basin circulatory ratio & $4 \pi \frac{A}{P^{2}}$ & $C_{k}[-]$ & 0.25 \\
\hline Basin mouth elevation & - & $\mathrm{H}_{\min }[\mathrm{m}$ a.s.I. $]$ & 54.3 \\
\hline Elevation of the highest point in the basin & - & $\mathrm{H}_{\max }[\mathrm{m}$ a.s.l. $]$ & 135.0 \\
\hline Height difference & $\mathrm{H}_{\max }-\mathrm{H}_{\min }$ & $\Delta \mathrm{H}[\mathrm{m}]$ & 80.70 \\
\hline Average basin elevation & $\frac{\mathrm{H}_{\max }-\mathrm{H}_{\min }}{2}$ & $\mathrm{H}_{\mathrm{s}}[\mathrm{m}$ a.s.I. $]$ & 94.65 \\
\hline River source elevation & - & $\mathrm{H}_{\mathrm{zr}}[\mathrm{m}$ a.s.I. $]$ & 94.1 \\
\hline Stahler relief ratio & $\frac{\Delta \mathrm{H}}{\mathrm{L}}$ & $\mathrm{C}_{\mathrm{f}}[\mathrm{m} / \mathrm{km}]$ & 2.42 \\
\hline Mean slope of the basin & - & $\mathrm{J}[\%]$ & 5.50 \\
\hline The Kopel river length & - & $\mathrm{L}[\mathrm{km}]$ & 32.38 \\
\hline $\begin{array}{l}\text { Distance from the spring to the mouth in a straight } \\
\text { line }\end{array}$ & - & $\mathrm{L}_{\mathrm{i}}[\mathrm{km}]$ & 23.14 \\
\hline Longitudinal slope of the Kopel river & $\frac{\mathrm{H}_{z r}-\mathrm{H}_{\min }}{\mathrm{L}} / 10$ & $\mathrm{~J}_{\mathrm{c}}[\%]$ & 0.12 \\
\hline Tortuosity of river ratio & $\frac{L_{i}}{L} 100$ & $k[\%]$ & 71.46 \\
\hline Total length of river network & - & $\mathrm{L}_{\mathrm{j}}[\mathrm{km}]$ & 481.19 \\
\hline Density of river network & $\frac{L_{j}}{A}$ & $\mathrm{G}_{\mathrm{s}}\left[\mathrm{km} / \mathrm{km}^{2}\right]$ & 1.14 \\
\hline
\end{tabular}

the daily flows in the dry years 1983 and 2004. These years were selected on the basis of annual minimum discharges (NQ). Most daily flows in these years varied between the mean of minimum flows (SNQ) and mean flow from the period 1972-2011 (SSQ). Only in February and March the daily discharges were higher than SSQ. It may be due to higher precipitation and snow melting in spring months.

The aim of the correlation analysis was to assess the relationship between meteorological conditions (temperature, precipitation) and drought parameters (duration, volume). In the first step such an analysis was performed for the same year. The analysis revealed no correlation between the meteorological and the drought parameters. In the second step, the drought indices were correlated with the meteorological parameters from the preceding year. For example, a correlation was checked between the drought indices from 2001 and the meteorological parameters from 2000. Negative correlations between all drought parameters and precipitation from the preceding year were found (Table 3). It means that low annual precipitation has a significant impact on the length of drought duration and drought volume. Decrease in precipitation leads to a reduction in the river flows. The analysis confirmed that hydrological drought occured later than meteorological drought. The difference in time between the meteorological and hydrological droughts depends on soil conditions, topography, land cover and meteorological conditions in previous years. Also a weak correlation between the mean annual temperature and drought parameters was obtained.

The direction of changes in the analyzed meteorological conditions and drought indices was established by analysis of trends. The results re- 
A

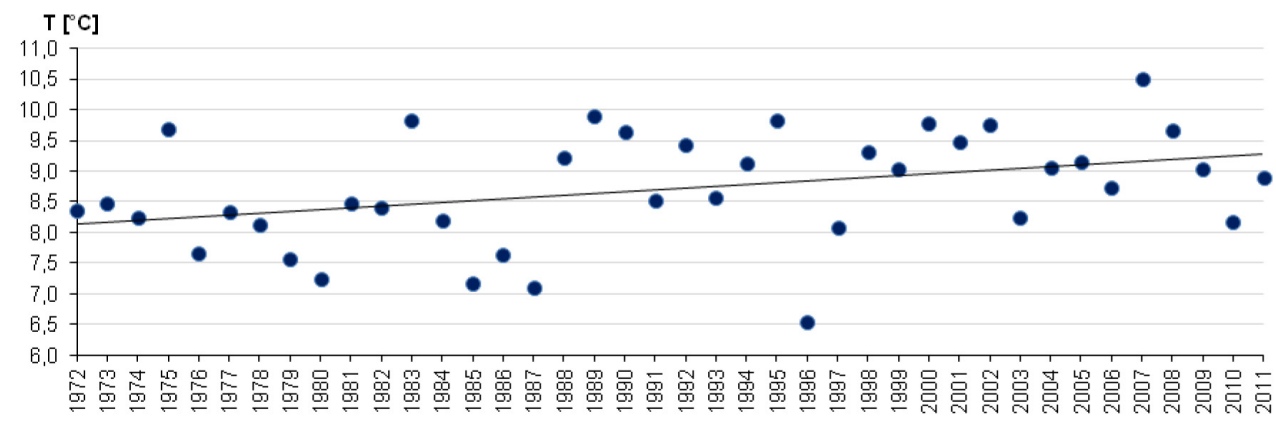

B

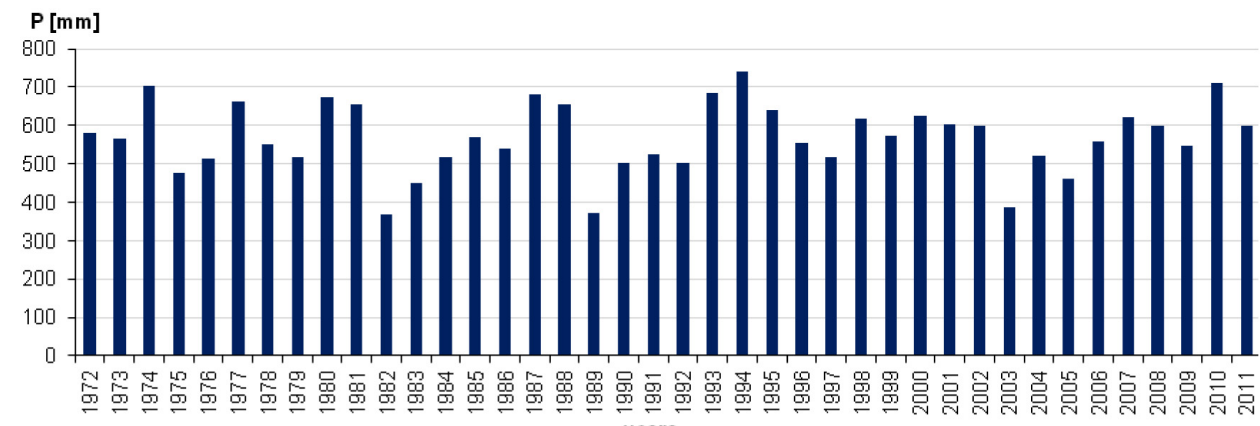

C

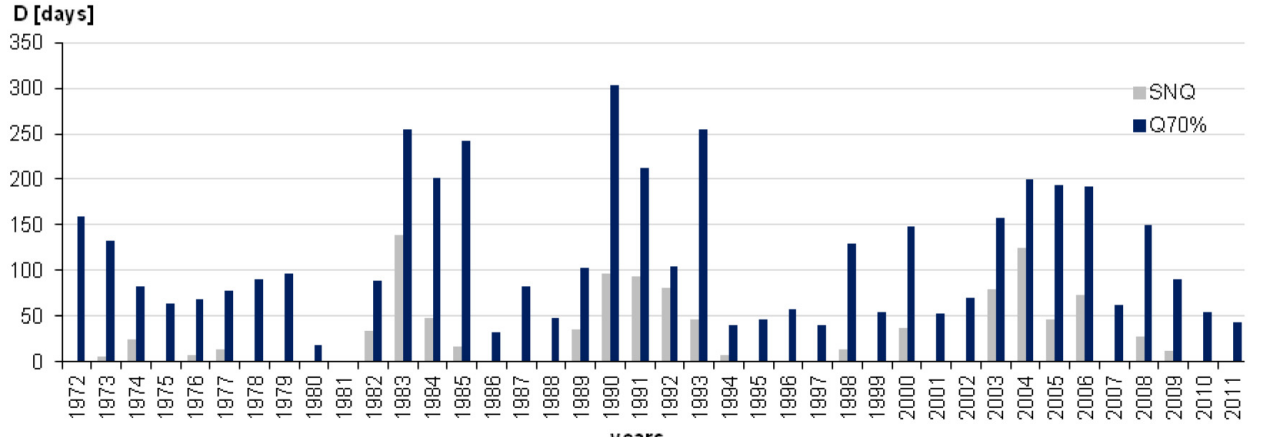

D

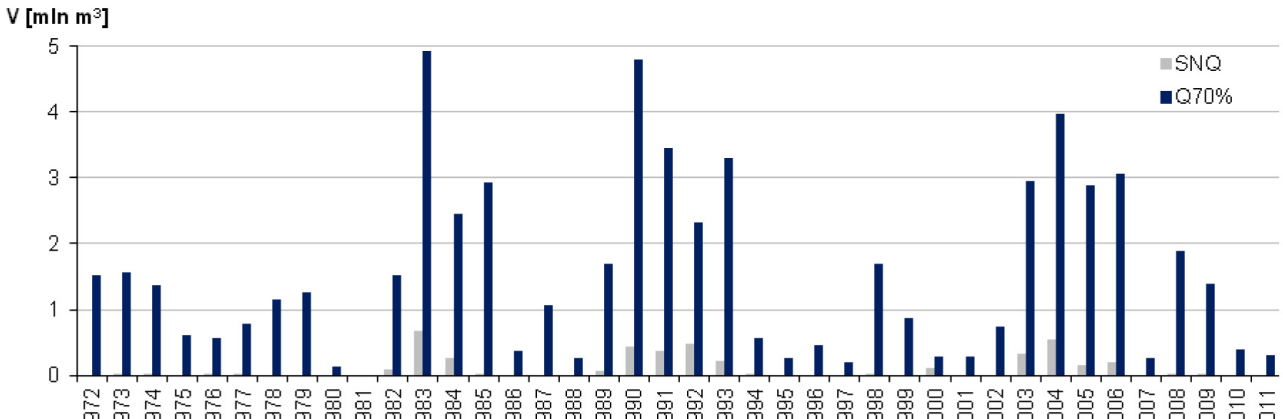

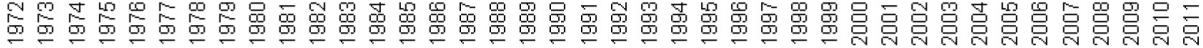
vears

Fig. 2. Annual values of meteorological and droughts parameters in the Kopel river basin in the years 1972-2011 A) temperature, B) precipitation, C) drought duration, D) drought volume

Table 2. Statistical characteristics of drought parameters in the Kopel river basin in the years 1972-2011

\begin{tabular}{|l|c|c|c|c|}
\hline \multicolumn{1}{|c|}{ Parameter } & $\mathrm{D}_{\mathrm{SNQ}}[$ days $]$ & $\mathrm{V}_{\mathrm{SNQ}}\left[\mathrm{m}^{3}\right]$ & $\mathrm{D}_{\text {Q70 }}[$ days $]$ & $\mathrm{V}_{\text {Q70 }}\left[\mathrm{m}^{3}\right]$ \\
\hline Minimum & 5 & 1938.8 & 19 & 127728.1 \\
\hline Maximum & 139 & 670081 & 303 & 4933677 \\
\hline Mean & 48 & 182780 & 115 & 1553720 \\
\hline Median & 36 & 99185 & 90 & 1267758 \\
\hline Standard deviation & 39 & 206172 & 73 & 1323715 \\
\hline Number of years with no drought days & 18 & - & 1 & - \\
\hline Sum & 1063 & 4021161 & 4503 & 60595063 \\
\hline
\end{tabular}




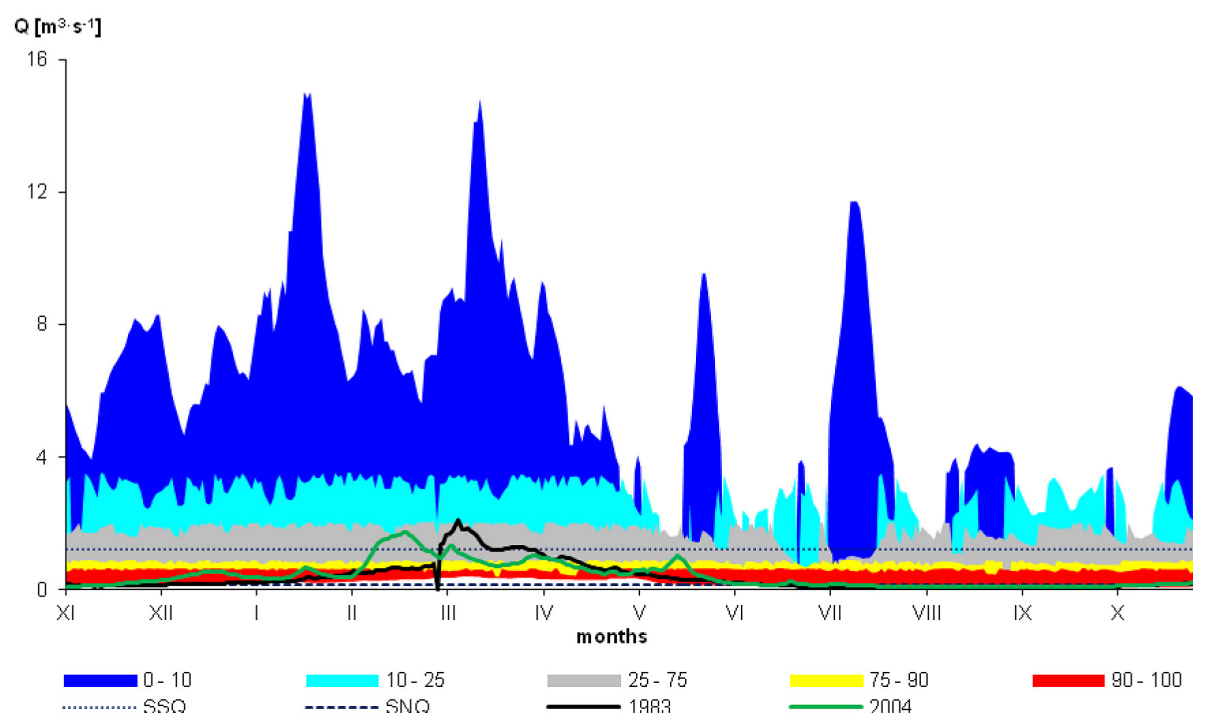

Fig. 3. The daily flows for 1983 and 2003 against the background of the sum discharge duration curve of the Kopel river in the years 1972-2011

Table 3. Correlation analysis of meteorological and droughts parameters in the Kopel river basin in the years 1972-2011 (Pearson's correlation coefficient)

\begin{tabular}{|l|c|c|c|c|c|c|}
\hline \multicolumn{1}{|c|}{ Parameter } & 01. & 02. & 03. & 04. & 05. & 06. \\
\hline 01. $\mathrm{T}\left[{ }^{\circ} \mathrm{C}\right]$ & 1.00 & 0.04 & 0.09 & 0.06 & 0.24 & 0.14 \\
\hline 02. $\mathrm{P}[\mathrm{mm}]$ & 0.04 & 1.00 & -0.66 & -0.67 & -0.70 & -0.70 \\
\hline 03. $\mathrm{D}_{\mathrm{SNQ}}$ [days] & 0.09 & -0.66 & 1.00 & 0.97 & 0.63 & 0.84 \\
\hline 04. $\mathrm{V}_{\mathrm{SNQ}}\left[\mathrm{m}^{3}\right]$ & 0.06 & -0.67 & 0.97 & 1.00 & 0.60 & 0.81 \\
\hline 05. $\mathrm{D}_{\mathrm{Q} 70}[$ days $]$ & 0.24 & -0.70 & 0.63 & 0.60 & 1.00 & 0.87 \\
\hline 06. $\mathrm{V}_{\mathrm{Q} 70}\left[\mathrm{~m}^{3}\right]$ & 0.14 & -0.70 & 0.84 & 0.81 & 0.87 & 1.00 \\
\hline
\end{tabular}

$\mathrm{T}$ - mean annual temperature, $\mathrm{P}$ - annual sum of precipitation, $\mathrm{D}$ - annual duration of drought, $\mathrm{V}$ - annual volume of drought.

vealed that temperature shows a statistically significant increasing tendency. The increase in the mean annual temperature $\mathrm{s}$ in the Kopel river basin over the period $1972-2011$ was $0.03^{\circ} \mathrm{C}$. The values of the other parameters showed no significant changes (Table 4).

\section{CONCLUSION}

The results of this study indicated that the Kopel river basin is highly vulnerable to drought risk. The analyses show that the trend of increasing temperature and high annual variation of precipitation in the period 1972-2011 with respect small water retention capacity lead to hydrological drought. The hydrological droughts were observed immediately after dry and very dry years. In these years, a gradual depletion of groundwater resources was observed. In the following years, deficits of precipitation did not allow the restora- tion of water resources in the catchments. Therefore the drought was more pronounced. According to Kowalczak [2001], the Kopel river basin was located in the area characterized by the high water deficit in the Warta river basin. The hydrological drought detection is crucial for monitoring and establishing it consequences. It would be recommendable to develop a warning system for the effective mitigation of the droughts-related damages. The essential part of resilience against droughts are also local hydro technical infrastructures - artificial irrigation systems, ponds and small reservoirs. They play an important role in water supply (for agricultural and social purposes), irrigation and protection of natural habitats in the rivers. Other solutions are related to landscape planning in the basin and include: release protective paths of flora, reclamation of wetlands and floodplain areas and sustainable development of transport routes. 
Table 4. Temporal trends in the meteorological and droughts parameters in the Kopel river basin in the years 1972-2011

\begin{tabular}{|l|c|}
\hline \multicolumn{1}{|c|}{ Parameter } & Trend significance \\
\hline 01. $\mathrm{T}\left[{ }^{\circ} \mathrm{C}\right]$ & + \\
\hline 02. $\mathrm{P}[\mathrm{mm}]$ & 0 \\
\hline 03. $\mathrm{V}_{\mathrm{SNQ}}[$ days $]$ & 0 \\
\hline 04. $\mathrm{V}_{\mathrm{SNQ}}\left[\mathrm{m}^{3}\right]$ & 0 \\
\hline 05. $\mathrm{D}_{\mathrm{Q70}}[$ days $]$ & 0 \\
\hline 06. $\mathrm{V}_{\mathrm{Q70}}\left[\mathrm{m}^{3}\right]$ & 0 \\
\hline
\end{tabular}

\section{REFERENCES}

1. Baryła A., Hewelke E., Stańczyk T. and Ptach W. 2016. Relative precipitation indexes in the Puczniew area. Scientific Review - Engineering and Environmental Sciences, 72, 156-166 [in Polish].

2. Bąk B., Kejna M. and Uscka-Kowalkowska J. 2012. Meteorological droughts in the region of the station of integrated environmental monitoring in Koniczynka (Chełmno Lakeland) in the years 1951 - 2010. Water - Environment - Rural Areas, 12, 19-28 [in Polish].

3. David V. and Davidová T. 2016. Assessment of Summer Drought in 2015 Using Different Indices in the Catchment of Blanice River. Procedia Engineering, 162, 45-55.

4. European Environmental Agency. 2008. Impacts of Europe's changing climate - 2008 indicator based assessment. EEA Report No. 4, JRC Reference Report No. JRC47756.

5. Esfahanian E., Nejadhashemi A.P., Abouali M., Adhikari U., Zhang Z., Daneshvar F. and Herman, M. R. 2017. Development and evaluation of a comprehensive drought index. Journal of Environmental Management, 185, 31-43.

6. Francés G.E., Quevauviller P., González E.S.M. and Amelin E.V. 2017. Climate change policy and water resources in the EU and Spain. A closer look into the Water Framework Directive. Environmental Science \& Policy, 69, 1-12.

7. Haro-Monteagudo D., Solera A. and Andreu J. 2017. Drought early warning based on optimal risk forecasts in regulated river systems: Application to the Jucar River Basin (Spain). Journal of Hydrology, 544, 36-45.

8. Hatmoko W., Raharja B., Tollenaar D. and Vernimmen R. 2015. Monitoring and Prediction of Hydrological Drought Using a Drought Early Warning System in Pemali-Comal River Basin, Indonesia. Procedia Environmental Sciences, 24, 56-64.

9. Huang S., Huang Q., Chang J., Leng G. and Xing L. 2015a. The response of agricultural drought to meteorological drought and the influencing fac- tors: a case study in the Wei River Basin, China. Agricultural Water Management, 159, 45-54.

10. Huang S., Huang Q., Chang J., Zhu Y., Leng G. and Xing L. 2015b. Drought structure based on a nonparametric multivariate standardized drought index across the Yellow River basin, China. Journal of Hydrology, 530, 127-136.

11. Huang S., Huang Q., Leng G. and Liu S. 2016. A nonparametric multivariate standardized drought index for characterizing socioeconomic drought: A case study in the Heihe River Basin. Journal of Hydrology, 542, 875-883.

12. Huang S., Li P., Huang Q., Leng G., Hou B. and Ma L. 2017. The propagation from meteorological to hydrological drought and its potential influence factors. Journal of Hydrology, 547, 184-195.

13. Huang W.C. and Chou C.C. 2008. Risk-based drought early warning system in reservoir operation. Advances in Water Resources, 31(4), 649-660.

14. Kanecka-Geszke E. and Smarzyńska K. 2007. Assessing meteorological drought in some agro-climatic regions of Poland by using different indices. Acta Scientiarum Polonorum. Formatio Circumiectus, (6)2, 41-50 [in polish].

15. Kędziora A., Kępińska-Kasprzak M., Kowalczak P., Kundzewicz Z.W., Miler A.T., Pierzgalski E. and Tokarczyk T. 2014. Risks resulting from water shortages. Nauka, 1, $149-172$ [in polish].

16. Kręgiel B. and Jarosińska E. 2009. Current condition of drought monitoring in Poland and all over the world. Technical Transactions - Environmental Engineering, 106, 87-99 [in Polish].

17. Kondracki J. 2002. Polish Regional Geography. PWN, Warszawa [in Polish].

18. Kowalczak P. 2001. Hierarchy of regional requirements of small-scale retention in the Warta catchment basin. Institute of Meteorology and Water Management - National Research Institute [in Polish].

19. Li Z., Hao Z., Shi X., Déry S. J., Li J., Chen S. and Li Y. 2016. An agricultural drought index to incorporate the irrigation process and reservoir operations: A case study in the Tarim River Basin. Global and Planetary Change, 143, 10-20.

20. Łabędzki L. 2004. Drought problems in Poland. Water - Environment - Rural Areas, 4, 47-66 [in polish].

21. Łabędzki L. and Bąk B. 2004. Differentiation of the atmospheric drought index SPI in the vegetation period in Poland. Water - Environment - Rural Areas, 4, 111-122 [in Polish].

22. Masud M.B., Khaliq M.N. and Wheater H.S. 2015. Analysis of meteorological droughts for the Saskatchewan River Basin using univariate and bivariate approaches. Journal of Hydrology, 522, 452-466.

23. Ministry of the Environment and the Institute of 
Environmental Protection - National Research Institute. 2013. Managing the Risks of Extreme Events and Disasters to Advance Climate Change Adaptation to 2020.

24. Mishra A.K. and Singh V.P. 2010. A review of drought concepts. Journal of Hydrology, 391(1), 202-216.

25. National Water Management Authority. 2010. Raster Hydrographical Map of Poland 1:50 000.

26. Pathak A.A. and Dodamani B.M. 2016. Comparison of two hydrological drought indices. Perspectives in Science, 8, 626-628.

27. Report of the Ministry of Environment for the river Odra basin area of the implementation art. 5 and 6 , est. II , III , IV of Directive 2000 / 60 / EC. 2005. [in Polish].
28. Tokarczyk T. 2008. Widly applied indices for drought assessment and Polish application. Infrastructure and Ecology of Rural Areas, 7, 167-182 [in Polish].

29. Wang K.Y., Li Q.F., Yang Y., Zeng M., Li P.C. and Zhang J.X. 2015. Analysis of spatio-temporal evolution of droughts in Luanhe River Basin using different drought indices. Water Science and Engineering, 8(4), 282-290.

30. Woś A. 1993. Climatic regions of Poland in the light of the frequency of various weather types. Polish Academy of Sciences, z. 20 [in polish].

31. Zhang Q., Xiao M. and Singh V.P. 2015. Uncertainty evaluation of copula analysis of hydrological droughts in the East River basin, China. Global and Planetary Change, 129, 1-9. 